\title{
The Microfinance Approach: Does it Deliver on its Promise?
}

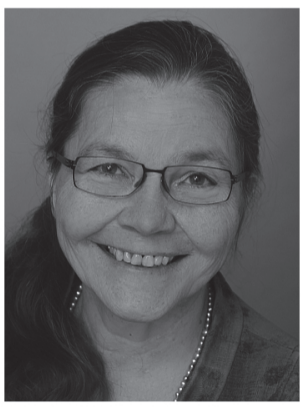

goes along with risk. Accordingly, the danger of over-indebtedness can be ameliorated by responsible finance practices, but never eliminated. Nevertheless, microfinance deserves its place as a development tool. Even if positive impacts are much smaller than claimed in the past, the impact stream is able to flow for as long as the microfinance supplier survives. As there is proof that temporary support can build sustainable institutions, the cost-benefit ratio still seems to speak in favour of the microfinance approach.

In den letzten Jahren sieht sich die zuvor hochgelobte Mikrofinanzierung massiver Kritik ausgesetzt: Mikrofinanzierung trage zur Gefahr von Überschuldung bei und habe bei der Armutsbekämpfung versagt. Der vorliegende Beitrag setzt sich mit diesen Vorwürfen auseinander, um zu einer realistischen Einschätzung des Mikrofinanzansatzes beizutragen. Es wird dargelegt, dass die Gefahr der Überschuldung durch verantwortungsvolle Kreditvergabe zu mildern, nicht aber gänzlich auszuräumen ist. Trotz dieses Risikos hat die Mikrofinanzierung ibren Platz als entwicklungspolitisches Instrument verdient, da ein dauerhafter Strom von zwar bescheidenen, aber doch überwiegend positiven Wirkungen, die durch neuere Messungen dokumentiert werden, den vergleichsweise geringen Kosten einer befristeten Unterstützung für den Aufbau von Mikrofinanzinstitutionen gegenüber steht.

\section{Motivation: impact crisis in microfinance}

"The Promise of Microfinance " was the title of Jonathan Morduch's seminal paper in the Journal of Economic Literature in 1999, for the first time introducing microfinance to a broader academic public. At the time, the title reflected rather accurately the spirit of all those politicians, donors or practitioners supporting the microfinance approach as a means to fight poverty in developing countries. A little more than a decade later, public opinion on microfinance has dramatically changed. Microfinance is accused of absorbing billions of donor funds while showing little or no effect on improving the livelihoods of the poor (Drake 2009; Harford 2009). Even more alarming, reports on microfinance clients in India appeared in the media who, in desperate situations of over-indebtedness, took to suicide as the apparent last resort (Biswas 2010). The question is posed in public 
whether for the poor microfinance has turned "from a blessing to a curse" (Wade 2010). In a nutshell, the utmost praise of microfinance in 2006, when Muhammad Yunus and the Grameen Bank were awarded the Nobel Peace Prize, became scepticism and even outright criticism merely a few years later.

The trigger, which caused this back swing in microfinance's media coverage, was twofold. On the one hand, the first few academic studies were published that attempted to rigorously measure the impact of microfinance by comparing the livelihoods of microfinance clients to a control group, which is similar to the client group in every respect except for a lack of financial access. The reported results fell short of what some promoters of microfinance had claimed, and made the hope of microfinance lifting millions out of poverty look like a mere illusion. On the other hand, the financial crisis in 2008/2009 revealed to everybody that microcredit is not without risk for its clients. In some overheated microfinance markets, which had shown annual growth rates in the double digits previous to the crisis, repayment rates dropped drastically and left an unknown number of clients in the state of over-indebtedness. Those who gave early warnings about the dangers of commercialisation in microfinance felt substantiated in their reasoning.

It is far from obvious, however, that the new evidence brought forward by rigorous impact studies and the aftermath of the financial crisis gives sufficient cause to overthrow everything supposedly known about microfinance, and to abandon all hopes of microfinance as an effective tool to improve the lives of low-income people in the developing world. After all, the financial crisis was a singular shock, and the evidence from over-indebted clients is primarily based on anecdotal evidence. Likewise, the evidence produced by rigorous impact studies is still scarce, and these studies are rather limited in what they can measure. Therefore, rather than premature rejection, recent evidence calls for a reassessment of the microfinance approach, of its potential achievements and its risks.

Contributing to such a reassessment is the motivation for this paper. A recapitulation of how the microfinance approach originated and what spurred the hopes going along with it will be combined with a review of what we know about microfinance's impact and what we don't. This shall form the basis of a realistic judgement on what can be expected when opening access to finance for those, who formerly had been excluded from formal financial services.

The rest of the paper is organised as follows. Chapter 2 briefly revisits the emergence of the microfinance approach in the 1990s; chapter 3 summarises the current knowledge on the risk of over-indebtedness which goes along with microcredit; chapter 4 puts the new evidence produced by rigorous impact analyses into perspective; chapter 5 concludes with some remarks on the virtues, the vices, and new challenges of the microfinance approach.

\section{The Microfinance Revolution - revisited}

What was the "promise of microfinance" all about, raising the hopes of access to finance as a way out of poverty? Following a period of disappointing results in all attempts to foster micro and small enterprise via directed lending in the 1970s and 1980s, a paradigm shift in the development approach brought about a change for the better. The provision of concessional credit lines reserved for those who were thought to be too poor to be bankable was replaced by the approach of building financial institutions (Krahnen/Schmidt 1994) specialised on serving the target groups formerly excluded from access to the formal 
financial system. The results of this paradigm shift, which took place in the early 1990s, were actually promising.

Donor funds, provided by means of directed lending, often went along with dismal repayment performance and frequently never even reached the target group due to adverse incentives produced by low interest rates. In sharp contrast, microfinance institutions (MFIs) supported by donor money for institution building managed to recapture the loans disbursed to micro entrepreneurs. Thanks to a credit-technology based on cash-flow assessment and graduation, rates of arrears stayed even below those of established banks in the same region. By the end of the 1990s, the 'microfinance revolution' - as it was frequently called - held the promise of offering a 'win-win' solution of suppliers and customers likewise profiting: After an initial phase of support for institution building, MFIs seemed to be able to offer financial services to the formerly underserved while covering costs or even producing moderate profits; and microfinance clients were receiving a sustainable access to formal financial services going along with new opportunities to smooth income and enlarge their businesses, thereby improving the livelihoods of their families or even transcending poverty. As such, microfinance appeared to be an extremely cost-effective approach to fight poverty: Once an MFI was built up and working, it was able to survive in the financial market on its own account. There was no need for further subsidies to keep open the window of opportunity which access to finance was offering to the poor.

The success story of microfinance spreading around the developing world seemed to confirm this way of thinking. Flagship MFIs were transforming into licensed banks without abandoning their target group of micro entrepreneurs and low-income households. At least in urban areas, these clients were getting access not only to microcredit, but also to other financial services like savings accounts and transfers of payments. Time intensive transformation of non-governmental organisations into professional banks was more and more often replaced by a 'greenfielding' approach, i.e. the foundation of fully-fledged microfinance banks right from the start. MFIs were getting less and less dependent on refinancing lines by donors, development banks or ethical investors. Instead, they were collecting local deposits or even tapping the capital market by issuing bonds. Singular micro banks in different countries were united in networks or under a holding to form micro banking groups, adding to knowledge sharing as well as improved liquidity and risk management. Since the turn of the millennium, specialised microfinance investment vehicles, refinanced by development finance institutions and ethical investors, have offered debt and equity finance to advanced MFIs; and on 20 ${ }^{\text {th }}$ April 2007, another milestone in the development of the microfinance sector was marked by the Initial Public Offering of the Mexican Banco Compartamos, an MFI founded in 1990 with grants from several donor sources (Rosenberg 2007). Microfinance was certainly on the way to becoming an integral part of the financial market.

By the end of 2008, shortly before the effects of the financial crisis had reached microfinance, the Microfinance Information eXchange, the most comprehensive database on microfinance, reported, based on the data of almost 1400 MFIs, that these institutions were reaching out to over $86 \mathrm{~m}$ borrowers and almost $96 \mathrm{~m}$ voluntary savers worldwide (Gonzalez 2009). The average loan balance per customer, a common proxy for target group orientation, was below USD 1,600. Furthermore, on average institutions were earning profits (return on equity $1.4 \%$ on average, median $8.9 \%$ ). There were regional differences as microfinance in Africa was clearly lagging behind. Furthermore, data on the Microfinance 
Information eXchange are positively biased as more successful MFIs are more likely to report. Nevertheless, hundreds of MFIs around the world were giving proof of what had seemed impossible before the microfinance revolution: The target group of micro entrepreneurs and low-income households can be financially served without continually loosing money.

However, progress in financial performance of MFIs was not equally welcomed as a success by all protagonists of the microfinance idea. With the IPO of Banco Compartamos in 2007, which attracted commercial investors not least because of the bank's high return on equity, warnings were getting louder that microfinance is loosing out on its original mission of helping the poor. Being hit by the financial crisis in 2009 put a definite halt to microfinance's boom. Reports on clients' over-indebtedness in the aftermath of the crisis as well as rigorous impact studies failing to prove noticeable poverty reduction effects of microfinance added to the doubts about financial success of MFIs automatically going hand in hand with benefits for the poor.

\section{Over-indebtedness - a widespread phenomenon in microfinance?}

\subsection{The downside risk in microcredit}

While microfinance now covers a wide range of financial services for low-income households, initially the microfinance movement was mainly associated with access to credit for micro entrepreneurs. Notwithstanding all the potential positive impacts of access to loans, borrowing money is never without risk.

On the creditor's side, risk is pretty well documented by rates of arrears and loan writeoffs. On the borrower's side, however, risk going along with borrowing is much more difficult to capture; its documentation is correspondingly weak. Often, information from the MFIs about repayment rates was and still is taken as a proxy for the degree to which borrowers have debt problems. The excellent repayment performance, which contributed to the high expectations put into the microfinance approach, was taken as a reliable signal for risks being rather low on the borrowers' side. However, there always were occasional warnings that taking arrears as a proxy might be missing out on something.

Back in 1996, Hulme and Mosley in their well-known book "Finance against Poverty" had already pointed out that borrowers might be worse off than before if they fail to repay, and they called for more intensified research on the livelihood of borrowers who drop out of a credit scheme (Hulme/Mosley 1996, 119-121). The authors were asking MFI staff for their estimations on the percentage of borrowers who have trouble meeting their loan obligations and who are likely to go bankrupt. Additionally, Hulme and Mosley collected anecdotal evidence on delinquent borrowers' suffering, e.g. when collateral was seized.

Actually, this is the borrower's downside risk of a credit contract. In contrast to equity finance, which shares the business risk between entrepreneur and equity provider more or less symmetrically, a credit contract does not spell out an equal participation in entrepreneurial risk. If the business goes well, the earnings exceeding the loan obligations will belong to the entrepreneur. If the business fails, however, it will always be the borrower who takes the first loss while the creditor only looses out once the borrower's repayment capacity is exhausted. Supporters of microfinance were well aware of this risk, commonly called financial leverage risk, when in the beginning of the 1990s the institu- 
tion building approach was developed. There were even some pilots and studies on micro equity finance in the form of venture capital. It just turned out to be too expensive, however, to provide small financial volumes as equity participation. ${ }^{1}$ There would not have been a realistic chance to turn micro venture capital into a cost-covering endeavour. Therefore, microcredit seemed to be the only option to create access to finance for the target group without the need for continual subsidies. Excellent repayment rates of microcredit as well as huge demand for this service laid remaining concerns to rest.

This changed, however, with microfinance turning into a business, particularly as suppliers entered the market that, under the flag of microfinance, started to roll out small consumer loans on a big scale. Already before the outbreak of the financial crisis, when microcredit was growing in double-digit annual rates, warnings on the danger of households' over-indebtedness were surfacing. ${ }^{2}$ Promoters of the microfinance approach as a development tool reacted with campaigns and principles for responsible finance (www.smartcampaign.org), to which institutions with a double mission, i.e. financial and social, readily committed themselves. This might not have been sufficient to protect microfinance clients, however, as the aftermath of the financial crisis made apparent.

\subsection{Household over-indebtedness - a phenomenon difficult to capture}

Whether the spreading of microcredit actually led to an increase in human tragedies most likely will never be clarified with certainty. However, knowing about the downside risk of borrowing provides sufficient cause to try to find effective ways for client protection. This is all the more important as the microfinance movement is spreading in low income countries, where the legal framework aiming at client protection is not yet very sophisticated. Even if laws, often initiated through the microfinance donors, to promote transparency of interest rates are more frequently put in place, and even if microcredit institutions are obliged to explain risks, e.g. going along with foreign currency loans, clients often have difficulties in understanding their contract terms nevertheless, due to a lack in financial literacy. The most important corner stones of client protection, which would have the power to effectively protect borrowers if they fail, are still missing in almost all microcredit markets in the developing world: A consumer insolvency law with debt relief combined with a formal social safety net. With these in place, an income on the subsistence level and the opportunity for a fresh start would be guaranteed also to those borrowers who get caught in a debt trap.

It is difficult to define at which point debt service becomes unbearable and the fine line is crossed between indebtedness and over-indebtedness (Hottenrott 2002, Alam 2012). Even functioning insolvency laws in developed countries face this challenge. Over-indebtedness as a legal term is usually reserved for companies with limited liabilities, describing a state in which liabilities exceed assets, and accordingly the company's equity is negative. When translating this definition into the context of an individual borrower, two difficulties arise. The inventory of an individual borrower's liabilities not only has to cover all personal debt, but also has to pin down a financial figure to represent future expenses to

1 Pretes (2002) promotes micro equity to avoid financial leverage risk. However, he underlines that micro equity in his definition is provided as a grant, and not as cost covering venture capital.

2 Potential problems coming along with growth rates of that magnitude can be manifold. A very important one in microfinance was a shortage in qualified staff. Recruiting and training could not keep up with the same pace as the portfolios were growing without loosing out on quality. 
guarantee a living at least on the subsistence level. Likewise, on the asset side, beside all tangible and financial assets to the borrower's name, the inventory will have to include an item for the human capital, representing the capacity to earn future income. Naturally, estimations of future income, most likely forming the most important asset of borrowers without material wealth, as well as an estimation of future living expenses is afflicted with a relatively high degree of uncertainty. That is why even in developed countries individual borrower's over-indebtedness is not a juridical term. Instead, not meeting debt obligations is taken as the trigger for individual insolvency procedures, which takes us back to where we started, that is arrears as a proxy for over-indebtedness.

Some countries, however, allow individuals to file for insolvency if they can prove it to be unlikely that they will be able to meet debt obligations in the future. This seems to be more adequate to protect clients from downside credit risk. Debt entanglement is likely to start much earlier than at the point in time when it becomes impossible to serve debt obligations. Not being able to turn anywhere for legal help when debt burdens are starting to become unbearable is particularly devastating for low-income borrowers in developing countries. As there is no formal social safety net, unlucky borrowers whose businesses fail might even continue the debt service although they urgently would need the little money they have for basic living expenses like food, school fees or medical expenses. Hardly anything systematic is known about the extent of struggling before borrowers actually fail on their debt obligations. A recent contribution to closing this knowledge gap, which Hulme and Mosley had pointed out more than 15 years ago, is an empirical research by Jessica Schicks (2010).

\subsection{The extent of over-indebtedness}

The extent of over-indebtedness, which is found in microfinance markets, clearly depends on the definition employed as well as on the research design. Schicks' research (Schicks 2010, 2012) aims at grasping over-indebtedness from a clients' perspective, and thereby laying the foundations for a pragmatic definition of over-indebtedness, which does not draw on the insufficient proxies of delinquency or failure to meet payment obligations. The research relies on 2010 data gained from structured interviews of more than 500 urban micro borrowers in Ghana. The interviewees were randomly sampled from the customer base of five well-known Ghanaian MFIs. Clients who were in arrears were slightly over-sampled to have a sufficient representation. The over-sampling was corrected for in the subsequent analysis by assigning weights to the different sample groups. During the interview, clients were confronted with a given list of potential "sacrifices", e.g. working more, eating less, taking children out of school, and they were asked to pick out those sacrifices, which they experienced in the context of recent loan repayments. In a second step, they were asked to rank on a scale of one to five whether they considered their individual sacrifices as acceptable (1) or totally unacceptable (5). In the case that a client frequently ( 3 times or more) suffered sacrifices rated as unacceptable, he or she was counted as overindebted. About 30 percent of the sample fell under this pragmatic and client-focussed definition of over-indebtedness. Interestingly enough, the urban Ghanaian microfinance market does not count as particularly riddled by problems of over-indebtedness, and according to the information systems of MFIs, rates of arrears were on a much lower and from their creditor's point of view a rather acceptable level. 
Obviously, this research is but a first step, and it is certainly no proof that borrower struggling is caused by micro loans. Being able to draw conclusions in that direction requires comparing interview results to those of a control group who is similar to the client group, except for not having to serve a loan. Actually, more rigorous research relying on a control-group approach could even reveal that households without any micro debt suffer even more because they are lacking the opportunity to smooth their consumption stream via borrowing. Almost all of the clients who took part in the interviews in Ghana and were classified as over-indebted firmly stated that they want to borrow again, some of them even higher amounts if possible. This is quite a firm indication that even those clients who suffer in serving their debt put a high value on financial access. Nevertheless, Schicks' results substantiate the suspicion that something important is left out when figures about portfolio risk and failure rates are the only inputs relied upon when estimating the extent of over-indebtedness.

More research, and specifically more research of a rigorous kind is needed to say more; and unfortunately the few results we do have (see Alam 2012, Schicks/Rosenberg 2011 for an overview) give few new ideas on what more could be done against the problem of overindebtedness. Closing the credit window is obviously not a viable option, as it would cut clients off from the upside potential of loans at the same time. Commitment to principles of responsible finance still seem to be the best preventive measure from the MFIs' side, including a careful assessment of clients' repayment capacity, an abdication of unethical methods of loan collection, an adaption of payment schemes to borrowers income streams, and an assessment of options for rescheduling in case of problems.

However, there is no way that responsible finance can compensate for a lack of official help for debt-trapped households, i.e. via an insolvency law providing a fresh start, or via formal social safety nets. As the downside risk of credit cannot be ruled out ex ante, it seems all the more important that for the vast majority of clients the potential positive impact of microfinance more than compensates for its risk. In this light, the existing evidence on microfinance's impact on the livelihood of the poor deserves the utmost attention.

\section{Impact measurement in microfinance - results and limitations}

\subsection{Control group designs to capture impact on microfinance beneficiaries}

The success story of microfinance as a tool to fight poverty was based predominantly on two pillars: Firstly, the achievements in building financially viable MFIs serving millions of customers formerly excluded from the formal financial system, and secondly an unaccounted number of anecdotes about how microfinance changed the lives of beneficiaries. The latter, however, are far from providing rigorous evidence that access to finance brought about the change for the better. Firstly, a before-after comparison, which is typical for anecdotes, fails to single out the influence of microfinance. It might have been simply an extraordinary entrepreneurial spirit of the owner (or something else), and not a microloan, which was pivotal in turning a tiny market stall into a thriving business. Secondly, the occasional story about a successful client might be cherry-picked from a pool of clients who on average were by far less fortunate.

Impact studies of an experimental or quasi-experimental design (Duflo et al. 2007) are promising to provide a more reliable foundation for microfinance's claim of benefitting the poor. Inspired by the methodology of pharmaceutical studies, these impact studies sta- 
tistically mimic a comparison between the situation with and without access to finance. With anecdotal evidence, a 'with versus without' comparison is impossible; it is contrafactual because a single person either can, or cannot, have access to finance. However, experimental impact studies circumvent this problem by comparing the target group of an intervention, in our case the customers of a microfinance institution, with a suitable control group. Ideally, the control group is as good as identical to the target group, except for the latter having access to finance, while the former is lacking it. The most reliable method to gain a target and a control group, which at least from a statistical point of view are identical, is to randomly divide a large group of individuals into those who receive the 'treatment' and those who do not. This random selection is reflected in the name of that experimental method, which is classified as most reliable, the so-called Randomised Controlled Trials (RCT). As can easily be imagined, it is as good as impossible to apply this method when aiming to measure the impact of microfinance. A random selection of individuals into target and control group might be possible if two financial products are tested against each other, but it hardly seems realistic to use a random selection if it is a question of access versus non-access. However, the strict methodology of RCT can be relaxed by applying a quasi-experimental design. There is a wide range of methods to define a control group in a quasi-experiment. The pipeline approach makes use of similar groups receiving the 'treatment' at different points in time. Accordingly, the group treated later in time can serve as the control group for those who are treated first. Propensity score matching is a method to artificially create a control group by finding an 'untreated' statistical twin for each target group member. In impact studies of microfinance, researchers usually try to identify a control town quarter or village, which is inhabited by community members very similar to those in the target area where a new branch of an MFI is going to open.

In the course of the (quasi-)experiment, data is collected from both groups, ideally before the intervention as well as afterwards. The 'double' difference in the average livelihoods of the two groups - given that both are large enough to statistically eliminate any random influence through the law of large numbers - allows for the isolation of microfinance's impact: The first difference of potential impact variables, e.g. business activities, income, education or health, is taken before the new financial window opens, and this difference will be close to zero if the two groups are selected well and accordingly are (almost) identical in a statistical sense. The second difference is taken after the target group receives access to finance. The improvement or deterioration in livelihoods in comparison to the control group, measured at the same point in time, gives the impact of microfinance (after correction for any difference between target and control group which was detected by the comparison before the intervention).

Experimental as well as quasi-experimental designs result in much more reliable impact measurements than any before versus after comparison can offer. However, the measurement is valid exclusively for the single intervention, which was the object of the study (internal validity). A larger number of impact studies of a similar kind are necessary to gain insights on whether results are of a more general nature and whether similar effects can be expected when the intervention in question is replicated in other settings (external validity). Systematic reviews offer a framework to analyse the question of external validity, given that a sufficient number of impact studies on a certain intervention type is entering into the review. According to the methodology of systematic reviews, only impact studies meeting the experimental or quasi-experimental standard are to form the base of analyses. The 
quality standard applied as well as the search process and range must be documented ex ante. Depending on the number and quality of studies, which enter a systematic review, it will deliver conclusions on whether impacts of the intervention in question show a low or a high variability subject to the regional, cultural or socio-economic setting.

\subsection{Rigorous impact studies on microfinance - results}

What is the rigorous evidence then, on which the microfinance approach can rely when trying to prove its benefit? While a few years back there was not even a handful of microfinance studies applying a control-group-approach, the body of evidence has become much larger in the last two years. Three systematic reviews have been published at this point. The first one, published in 2010, focussed on Sub-Saharan Africa (van Roojen et al. 2012); it is based on 15 impact studies in 10 countries. The second review by Duvendack et al. (2011) relies on evidence worldwide provided by 58 studies in 19 countries. The third review (Pande et al. 2012) includes 12 studies in 10 countries worldwide. At least one more systematic review focussing on evidence from the Asian region is in the process of being conducted (Stewart et al. 2011). Only a small minority of the individual studies actually follows the gold standard of RCT design. Most studies aim at measuring the impact of microcredit; in single cases the question of impact is addressed for agricultural credit, micro savings, micro insurance, micro leasing or new banking technologies.

All in all, the impact of microfinance, which was observed, was rather moderate, and certainly fell short of the "Microfinance Promise" of lifting millions of people out of poverty. There is quite reliable evidence from several studies that access to microcredit actually had positive effects on entrepreneurial activities, e.g. the foundation of new businesses or the enlargement of existing ones. Likewise, positive effects on acquiring durable goods were found. There is little evidence, however, that microfinance led to a general improvement of livelihoods. Several studies find no effect on income or general well being; single studies, particularly in Sub-Saharan Africa, conclude positive effects on income, health or the quality of housing and food. However, there is occasional evidence as well that access to microloans, particularly if the money was not invested, but used for consumption purposes, increased vulnerability or had negative effects on the schooling of children. Parallels to the results of Schicks' study on over-indebtedness are evident.

Quite frankly, this is no overwhelming proof of microfinance's power to fundamentally change the lives of the poor. It can be concluded that microfinance certainly is no magic bullet to fight poverty, and there is no rigorous evidence that microfinance turns subsistence-level enterprises into flourishing small firms on a large scale. However, microcredit can support entrepreneurial activity on a moderate level, and it can help to accumulate durable assets, perhaps even help to moderately improve income and living conditions in general. These potential benefits come for the price of additional risk, particularly if the loan is used for consumption.

Certainly, the evidence provided by rigorous impact studies is still preliminary, but it seems sufficient to put "The Promise of Microfinance" into a more realistic perspective. Advocates of the microfinance approach need to be much more moderate about what can be achieved by providing access to financial services.

However, existing evidence neither seems to justify extremely negative media coverage, nor gives it any reason to abandon the microfinance approach as a development tool alto- 
gether. Even the pioneers of RCT who, besides other interventions, have conducted the probably most well-known impact studies on microfinance, come to conclude:

"As economists, we were quite pleased with these results: The main objective of microfinance seemed to have been achieved. It was not miraculous, but it was working. In our minds, microcredit has earned its rightful place as one of the key instruments in the fight against poverty." (Banerjee/Duflo 2011, chap. 7)

\subsection{Limits of rigorous impact studies in microfinance}

A pessimistic outlook on the future of microfinance based on existing rigorous evidence seems unjustified, especially as the systematic reviews clearly point out that there are a very limited number of studies yet which meet the required quality standard. This is not really astonishing, as building microfinance institutions is a type of intervention, which is not ideally suited to apply experimental or quasi-experimental designs. In contrast to clearly targeted 'treatments', microfinance interventions serve the target group in a more indirect way. MFIs open a window to access financial services; the clients decide by themselves whether they want to use that opportunity. This causes a problem of selection bias, which is difficult to eliminate in impact studies.

There are other shortcomings of existing impact studies that are unlikely to be overcome by future research. Most importantly, almost all of them were conducted during the last few years. However, the Microfinance Revolution started more than two decades ago. By now, MFIs have long spread out all over the developing world, most likely placing branches in the most promising locations for their mission. Accordingly, it will hardly be possible anymore to find a target group and a control group untouched by microfinance exactly in those locations, which had the highest impact potential in the past. Methods of rigorous impact analyses were simply applied too late; most probably, more impact would have been found if measurement had taken place when microfinance was still in its infant shoes. Indirectly, this hypothesis is gaining some support by the latest systematic review (Pande 2012). It reports particularly high impacts found in studies on financial services which were introduced as an innovation in the respective development context, i.e. agricultural loans or mobile banking. Beside the shortcoming of measuring the impact, particularly of microcredit interventions in urban areas, too late, it seems of minor importance that the vast majority of existing studies cover timeframes of no more than 18 month, which is too short to discover potential long-term impact.

What rigorous impact studies fail to capture as well, are all potential impacts of microfinance interventions on the financial system as a whole. Besides its direct benefit for microfinance clients, financial system development is usually an additional goal associated with microfinance interventions. Undoubtedly, the microfinance approach has served this purpose in several respects. Beside micro clients, MFIs offer their service to small and even medium enterprise, which were not adequately served by the banking system before. These clients, not having been the subject of rigorous impact analyses yet, might have a much higher potential in job creation than micro clients. Additionally, tens of thousands of MFI staff members were trained, often with donor support. This most likely contributed to the professional standard in the financial sector, all the more as trained staff often moved on to other banks. Furthermore, in many developing and transition countries MFIs served as role models for good governance: they were actively pushing for client protection, and they were pioneers in their commitment to principles of responsible finance. 


\section{Conclusions}

Without doubt, the reputation of microfinance suffered during its crisis. However, microfinance survived the crisis, and, in my view, it came out of it healthier than before. Support for microfinance or any other development tool that is based on naïve perceptions, unrealistic expectations, or a lack of knowledge of the public can hardly be a solid foundation for development success in the long run. Before the crisis, there was a certain degree of over-promising concerning microfinance's impact on the livelihoods of the poor, at least by some advocates of the microfinance approach; and the remarkable growth rates of microcredit portfolios gave further nourishment to over-optimistic expectations. The microfinance crisis with its financial and its impact dimension has put this back into perspective. Microfinance certainly is no magic bullet against poverty, and its positive potentials for improving the livelihoods of low-income people do not come without risk.

The downside risk of credit on the borrower's side, namely the risk of having to struggle to repay or even being caught in a debt-trap, can be mitigated by means of thorough credit analysis, transparency, and customers' education in financial matters. However, the risk hardly ever can be eliminated because it cannot be ruled out that the client suffers a severe shock and repayment capacity falls well below former expectations. Actually, the spreading of microfinance and MFIs diminished the scope of individual MFIs for controlling credit risk of single customers as competition in the microfinance market usually comes along with a rising number of clients borrowing from multiple sources. This is all the more worrying as the success of the microfinance approach has attracted other players who just try to make a business, not least with consumer loans, without safeguarding against the dangers of over-indebtedness which are borne by the low-income customer. Credit bureaus are important agents that can help MFIs keeping track of clients' overall credit history; that is why the establishment of such bureaus has been promoted by the same donors for quite some time that are supporting microfinance. Despite of these improvements, it will still take a lot more in developing countries to round off the institutional set-up of client protection, namely by the establishment of insolvency laws for private individuals allowing relief from unsustainable debt, and of social security systems which can guarantee an income on the subsistence level. Therefore, it will remain of utmost importance that MFIs with a financial and a social mission use all their options to secure positive impacts for their clients as best as they can, first and foremost by providing financial services in a responsible way.

Microfinance's potential for positive impacts on clients' livelihoods has been demonstrated, even if measured impacts, particularly of microcredit, stayed well behind of what was hoped for. Impacts of microfinance on financial sector development, i.e. via training of staff, the promotion of transparency, good governance, or principles for responsible finance, have never been measured; nevertheless, they are existent. Last but not least, when assessing the achievements and the future potential of microfinance, it is not to be forgotten how it all began. Without doubt, there is a striking success that the microfinance approach can righteously claim as its own: The creation of viable target-group-oriented financial institutions, which after an initial phase of institution building can survive without continually being fuelled with additional subsidies. As long as access to finance goes along with predominantly positive impacts for its clients, these impacts will flow for as long as the MFI survives. Accordingly, the microfinance approach seems to offer a very favourable cost-benefit relation, even if impact on individual clients in a single time period 
is small. The example of the German savings banks, ${ }^{3}$ founded in the beginning of the $19^{\text {th }}$ century with a mission very similar to that of the MFIs of today, give vivid evidence of sustainable institutions serving the target group of micro and small enterprises as well as low- and medium-income households, by now for as long as about two centuries.

\section{References}

Alam, S.M. (2012): Does Microfinance create over-indebtedness?, Working Paper, under http://ssrn. com/abstract $=2070616$.

Banerjee, A.V./Duflo, E. (2011): Poor Economics: A Radical Rethinking of the Way to Fight Global Poverty, New York.

Biswas, S. (2010): India's micro-finance suicide epidemic, under www.bbc.co.uk/news/world-southasia-11997571 (12.8.2012).

Drake, B. (2009): Small Change, in: The Boston Globe 20.9.2009, under http://www.boston.com/bo stonglobe/ideas/articles/2009/09/20/small_change_does_microlending_actually_fight_poverty/ (12.8.2012).

Duvendack, M., et al. (2011): What is the evidence of the impact of microfinance on the well-being of poor people? Research Report,EPPI-Centre, Social Science Research Unit, Institute of Education, University of London.

Duflo, E./Glennerster, R./Kremer, M. (2007): Using Randomization in Development Economics Research: A Tool-Kit, in: Handbook of Development Economics, Vol. 4, pp. 3895-3962.

Gonzalez, A. (2009): Microfinance at a glance - 2008, Microfinance Information eXchange, Washington D.C.

Guinnane, T.W. (2011): The Early German Credit Cooperatives and Microfinance Institutions Today: Similarities and Differences, in: Armendáriz, B./Lapie, M. (eds): Handbook of Microfinance, London-Singapore, pp. 77-100.

Harford, T. (2009): Perhaps microfinance isn't such a big deal after all, in: Financial Times 5.12.2009, under http://www.ft.com/cms/s/0/ae4211e8-dee7-11de-adff-00144feab49a.html (12.8.2012).

Hottenrott, V. (2002): Die Überschuldung privater Haushalte in Deutschland vor dem Hintergrund der neuen Insolvenzordnung, Diss., University of Heidelberg.

Hulme, D./Mosley, P. (1996): Finance against poverty, Vol. 1, London.

Morduch, J. (1999): The Promise of Microfinance, in: Journal of Economic Literature, Vol. 37, pp. 1569-1614.

Krabnen, J.P./Schmidt, R.H. (1994): Development Finance as Institution Building, Boulder, Col. 1994.

Pande R., et al. (2012): Does Poor People's Access to Formal Banking Services Raise their Incomes? EPPI-Centre, Social Science Research Unit, Institute of Education, University of London.

Pretes, M. (2002): Microequity and Microfinance, in: World Development, Vol. 30, No. 8, pp. 1341-1352.

Rosenberg, R. (2007): CGAP reflections on the Compartamos Initial Public Offering: A case study on microfinance interest rates and profits, CGAP Focus Note No. 42, Washington D.C.

Wade, M. (2010): From a Blessing to a Curse, under http://www.theage.com.au/national/from-a-bles sing-to-a-curse-20101213-18vjo.html (12.8.2010).

3 Another example is provided by the German credit cooperatives (Guinnane 2011). 
Schicks, J. (2010): Microfinance Over-Indebtedness: Understanding its drivers and challenging the common myths, Centre Emile Bernheim (CEB) Working Paper No. 10/048.

Schicks, J. (2012): Over-indebtedness in Microfinance - an empirical analysis of related factors on the borrower level, Centre Emile Bernheim (CEB) Working Paper No. 12/017.

Schicks, J./Rosenberg, R. (2011): Too much Microcredit? A Survey of the Evidence on Over-Indebtedness, CGAP Occasional Paper No. 19.

Stewart, R./van Roojen, C./de Wet, T. (2011): Do micro-credit, micro-savings and micro-leasing serve as effective financial inclusion interventions enabling poor people, and especially women, to engage in meaningful economic opportunities in LMICs? EPPI-Centre, Social Science Research Unit, Institute of Education, University of London.

Van Roojen, C./Stewart R./de Wet, T. (2012): The Impact of Microfinance in Sub-Saharan Africa: A Systematic Review of the Evidence, in: World Development, forthcoming.

Eva Terberger, Dr., is Professor for Financial Systems and Development Finance at the Business School, University of Mannheim. She is on temporary academic leave of absence to head the Financial Cooperation Evaluation Unit at KfW Entwicklungsbank.

Address: University of Mannheim, Chair of Business Administration, esp. Financial Systems and Development Finance , L9, 1-2, D-68138 Mannheim, E-mail: eterberg@mail.unimannheim.de 